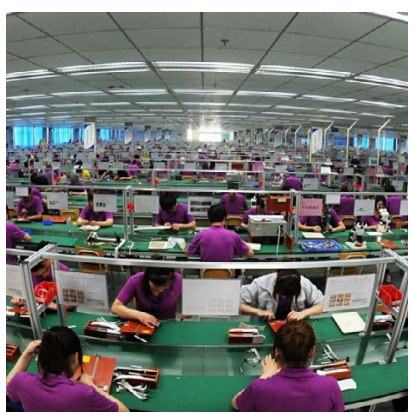

PC: Bilaterals.com

\section{Trade Union Reform in China: An Assessment}

Geoffrey CROTHALL

$\mathrm{W}$ hen Xi Jinping formally launched China's trade union reform initiative in November 2015, it was not exactly headline news (Workers' Daily 2017). The announcement, couched in typically impenetrable Partyspeak, appeared to be just another vaguely-worded commitment to the reform process.

However, what China's trade unions do and, just as importantly, do not do can have a tremendous socioeconomic and political impact. If carried out effectively, the trade union reform initiative has the potential to benefit not just China's workers but also bolster the political legitimacy of the Communist Party-hence the push from the very top of the Party.

With an estimated 300 million members and one million full-time officials, the All-China Federation of Trade Unions (ACFTU) is uniquely placed to help improve the pay and working conditions of China's workers. Up until now, however, it has singularly failed to do so. After four decades of economic reform, the majority of China's workers have yet to really benefit from the country's so-called 'economic miracle', while on the other hand a small number of Party and business leaders have become obscenely wealthy. Moreover, this extreme wealth inequality has actually worsened over the last five years, as China's fast-paced economy slows down and an ever-increasing number of workers are consigned to low-paid, precarious employment with little or no welfare benefits.

At the end of 2015, the Party leadership understood that there was a pressing need for the ACFTU to shake off its bureaucratic torpor and rededicate itself to helping workers obtain a fair share of the national wealth. The task was made even more urgent by the fact that the authorities were simultaneously cracking down on several civil society labour organisations in Guangdong that had actually been helping workers-in other words, doing the job the ACFTU should have been doing all along (Franceschini and Lin 2018).

Over the following years, the ACFTU claimed in an endless stream of speeches and policy documents that it had got the message. However, working conditions did not improve and 
workers continued to stage thousands of strikes and collective protests each year over wage arrears, lay-offs, and unpaid social insurance contributions (Crothall 2018).

In the summer of 2018, China Labour Bulletin (CLB) decided to investigate just how effective the trade union reform initiative had been by talking directly to trade union officials on the ground rather than relying on the ACFTU's official pronouncements. As CLB Executive Director Han Dongfang explained: 'Instead of trying to prove once again that the ACFTU was useless and that the reform initiative was just another fake event, we wanted to use labour dispute cases in which workers were in urgent need of union representation to knock on the door of local unions and discuss whether or not they can act on the workers' behalf, if so how and if not, why not.'

From August 2018 to June 2019, we conducted about 250 telephone interviews with 95 local trade unions, based on 71 collective worker protests in 12 provinces. Initially, we would ask the officials whether or not they were aware of a specific labour dispute in their area and, if so, what had been their response to it; had they intervened to help the workers defend their rights, mediated in the dispute or sought to negotiate with the employer to resolve it, or had they simply ignored the workers' plight? The discussion could then broaden out to a critique of the union's performance and the difficulties officials had in organising workers, resolving labour disputes, and implementing the trade union reform agenda.

While some officials were suspicious and reluctant to talk, many were open to our inquiries and talked frankly about their own roles, their frustrations, and their hopes for improving the lives of workers.

This research formed the basis of a comprehensive report, which was published in December 2019 and subsequently sent to more than 100 trade union offices around the country for their comment (CLB 2019).

In essence, the main findings of the report were that although the ACFTU has made some efforts to help defend workers' rights since the onset of the reform initiative, enterprise unions remained far removed from the workers they were supposed to represent and trade union officials had little understanding of what genuine collective bargaining entailed, and spent most of their time on activities unrelated to the core mission of a trade union. 
Collective bargaining, likewise, remained a largely formulaic exercise with officials concerned more with the number of collective agreements signed than the relevance of those agreements to the workers they were supposed to help.
Many local trade unions devoted more financial and human resources towards providing workers with legal advice and helping them defend their rights in disputes with their employer. This is a much-needed service given that China's labour arbitration and mediation committees handle more than a million complaints each year, according to official data from the National Bureau of Statistics. By the time of our investigation, most district- and county-level trade union federations had established worker service centres and rights protection hotlines, and responded positively to workers' requests for help. Some of the officials we talked to were clearly dedicated to the cause and saw themselves as genuine representatives of labour.

When it came to what should be the core activities of trade union officials, worker organising and collective bargaining, however, the results of our investigation were more disappointing. The ACFTU has acknowledged that employment conditions in China are changing and that there is a need to focus more on workers in the service and transport sector rather than the traditional manufacturing sector, which is now in decline. In April 2018, as part of the reform initiative, the ACFTU launched a new campaign designed to bring more transport and service workers into the union, concentrating on eight major groups: truck drivers, couriers, nursing staff, domestic staff, security guards, online food delivery workers, sales and real estate agents (Li and Deng 2018). In the following months, local unions proudly publicised how they had worked hard to bring the eight groups into the fold; however, they still followed the traditional model of setting up enterprise trade unions based on quotas established by higher-level unions rather than on the actual needs of workers on the ground. Moreover, many local union officials were constrained or frustrated in their efforts to recruit workers by the union's bureaucratic structure and rigid requirements of their superiors.

Collective bargaining, likewise, remained a largely formulaic exercise with officials concerned more with the number of collective agreements signed than the relevance of those agreements to the workers they were supposed to help. A veteran trade union official from Wuhan who we talked to was quite candid in his assessment of his own work in negotiating collective wage agreements in the construction industry. Wage levels were not the main concern of construction workers, he explained, rather work safety and the chronic problem of wage arrears were the main issues workers wanted to resolve. However, these grievances were never part of the collective bargaining process. 
Once in place, sectoral unions would be able to develop collective bargaining strategies specifically tailored to the needs of their members.
Nearly all trade union officials spend far too much time on government poverty relief efforts, educational and training programmes, helping with employment searches, even marriage introductions, and celebrating great craftsmen and model workers etc., tasks that should never be part of a trade union's core work. Poverty alleviation is one of Xi Jinping's most important crusades, and as such trade union officials in remote and poor districts of China have been recruited to make sure all poverty eradication targets are met by the end of 2020 . This, of course, diverts resources away from helping workers in those areas resolve disputes with their employer and improve their working conditions.

It became clear from our interviews with trade union officials that a lot of the ACFTU's problems stemmed from its overbureaucratic, hierarchical structure and reliance on orders from above.

To resolve this deep-seated problem, the report recommended a complete overhaul of the ACFTU's organisational structure that would place industrial and sectoral trade unions at its core. These sectoral unions would reflect local employment conditions so that regions with a high concentration of garment factories, for example, would have a garment workers' union, while urban centres would have more service sector and white collar unions. Nearly all districts would have construction and transport worker unions. These sectoral unions would eventually replace the current provincial, municipal, and district trade union federations that are in essence just an adjunct of the local Party and government. Staff from those federation offices would be redeployed to the sectoral union best suited to their capabilities.

Once in place, sectoral unions would be able to develop collective bargaining strategies specifically tailored to the needs of their members. The report outlined what some of these strategies might look like for the construction industry and transport sector. In the construction industry, the report suggested building a database of all workers that would not only help the union negotiate appropriate collective agreements that included pay levels, working hours, social insurance, work safety, etc., but would also allow the union to offer skills training and match specific workers to employment opportunities in individual construction projects in their region.

Another vital area of reform identified by the report is the need for union officials to reposition themselves as representatives of, and advocates for, workers, and abandon their current role as propagandists for the Communist Party. 
The report stressed that enterprise union officials must be part of, and democratically elected by, the workforce, and should be imbued with socialist values so as to effectively combat the corporate greed and lawlessness that currently pervades much of the private sector in China.

Finally, the report made a very concrete recommendation that the ACFTU should establish a comprehensive online presence in one general website that lists the contact information for all regional and sectoral trade unions across the country, as well as the names and profiles of the relevant officials. This would enable workers and union members to quickly identify and contact the trade union most suitable for their needs and most likely to resolve their grievances. Currently, each local union has its own (usually poorly maintained) website or Weibo/ WeChat account which appears to be completely disconnected from other unions.

Going forward, CLB will continue to monitor and report on the progress of China's trade union reform. In the coming months, we will focus in particular on how union officials are responding to labour disputes in the construction and transport sectors, as well as what the union is doing to help workers during the COVID-19 outbreak.

While there is no guarantee that officials in the ACFTU will listen to our proposals, it is vital that we keep applying pressure. As Han Dongfang noted: 'We need to keep trade union officials' feet to the fire so that they can either choose to keep rejecting workers' demands for representation or start learning how to act as a real union.' 
This text is taken from Made in China Journal: Volume 5, Issue 1, 2020, edited by Ivan Franceschini, Nicholas Loubere and Christian Sorace, published 2020 by ANU Press, The Australian National University, Canberra, Australia.

doi.org/10.22459/MIC.05.01.2020.02 